\title{
Note on the Translation
}

My aim in translating Montaigne has been to capture in modern English not only his meaning but also the living, natural quality of his style. I have deliberately chosen to retain, as he did, as many as possible of the idiosyncrasies that portray him: the vivid, bold images; the epigrammatic word play; the meandering, associative order, often disdainful of logical connectives; the obscenity, which is a studied protest against man's rejection of the body. I have smoothed the rough spots over only when they seemed less characteristic of Montaigne than of his time or when the claims of intelligible English seemed clearly to outweigh those of scrupulous fidelity. I have tried, in short, to express Montaigne as I think he would have expressed himself had he been writing in English today.

The basic text of the Essays followed here is the Bordeaux Copy, a copy of the 1588 (5th) edition which Montaigne, in his own hand, marked "6th edition" and covered, in the margins, with additions. This volume, preserved in the Municipal Library of Bordeaux, has been reproduced phototypically by Fortunat Strowski (Paris: Hachette, 1912). A copy of the additions was sent to Montaigne's literary executrix, Marie de Gournay, and served as a basis for her first edition of 1595. This 1595 text, though not always wholly trustworthy, is useful in two ways: it gives readings that were later cut from the margins of the Bordeaux Copy by a heedless binder in trimming the pages, and also readings that Montaigne may have relegated to separate slips of paper which have since been lost. Readings of the former type from the 1595 edition are included in the present translation without comment; those of other types have usually been either noted in the text or relegated to footnotes with the other variants.

Variants from earlier editions of the Essays (1580, 1582, 1587), as well as post-1588 additions that were deleted after being written, have been given in the footnotes whenever they seemed interesting enough to warrant mention.

Montaigne's text abounds in quotations in prose and verse, mainly Latin but also Italian, Greek, and French, without indication of source. In the present translation these have been given solely in English, italicized when in prose, and with the author's name added. The translations of the verse quotations are my own. They represent the form that Montaigne quotes, even when he adapts or misquotes. I have tried to be faithful to their meaning in the context Montaigne gives them, in which precision is often important.

Originally each chapter of the Essays was set as a single paragraph. The present translation follows modern usage in breaking up these long paragraphs. Bracketed subheads are introduced for the reader's convenience into the huge "Apology for Raymond Sebond" (II: 12). 
The superscript letters $\mathrm{ABC}$ in the text serve to distinguish the three certain strata in which the Essays were composed:

A designates material published before 1588 (generally in 1580 unless otherwise noted);

B designates material published in 1588;

C designates material published after 1588 .

This device is a variant of those used in the editions by Strowski, Villey, Plattard, and Thibaudet, and in the translations by Ives and Zeitlin. It is necessary for almost any serious study of Montaigne and often for the simplest comprehension. Often in the same chapter-I: 14, II: 6, and II: 18 are good examples-additions of 1588 or later show a very different attitude from that of the original text in which they are set. An attentive reader unaware of these strata is likely to find Montaigne puzzling and may write him off as irresponsibly inconsistent. The Essays are intended to be a record of change, and the strata indicators help to make this change clear.

Montaigne sometimes alters his original phrasing but keeps his sentence structure, with the result that it is not always possible to read the earlier strata continuously. When changes of this sort are substantive, the revised passage has usually been attached entirely to the later stratum, in order to avoid the danger of attributing later remarks to an earlier period.

Several chapters of the Essays-here considerably revised-were published in another form in 1943 by Walter J. Black, Inc. and in 1948 by F. S. Crofts \& Co., Inc.

I wish to take this opportunity to thank the staff of Stanford University Press-especially Jesse G. Bell, Jr., and J. Christopher Heroldfor their constructive criticism, counsel, and suggestions, in helping to prepare this volume for publication. An especially cherished debt is to my wife, Katharine Mailler Frame, for constant encouragement, ready advice, and a willing ear.

\section{SELECTED BIBLIOGRAPHY}

EDITIONS

Essais. Ed. by Fortunat Strowski et al. 5 vols. Bordeaux: Pech, 190633. "Edition Municipale." Gives all variants of all six basic editions. Essais. Ed. by Fortunat Strowski. Hachette, ${ }^{1}$ 1912. Phototypic reproduction of "Bordeaux Copy," showing all Montaigne's handwritten additions of 1588-92.

Essais. Ed. by Pierre Villey. 3 vols. Alcan, 1922-23. Gives strata indications and dates of composition of essays.

Essais. Ed. by Pierre Villey. 3 vols. Alcan, 1930-31. Superb scholarly reader's edition. Gives strata indications and dates of composition.

Essais. Ed. by Jean Plattard. 6 vols. Roches, 1931-33. Reprinted by the Société Les Belles Lettres in 1946-48. Gives strata indications. noted.

1 All books listed in this Bibliography are published in Paris unless otherwise 
Essais. Ed. by Albert Thibaudet. Gallimard, 1934; reprinted with different pagination, 1950. Pléiade edition. The handiest of all and the best all-round edition currently available. Gives strata indications.

L'Italia alla fine del secolo XVI. Giornale del Viaggio di Michele di Montaigne in Italia nel 1580 e 1581. Ed. by Alessandro d'Ancona. Città di Castello: Lapi, 1889. French text, valuable notes in Italian on persons and places mentioned.

Journal de Voyage. Ed. by Louis Lautrey. Hachette, 1906. Offers bold and useful conjectural emendations to text.

Journal de Voyage. Ed. by Arthur Armaingaud. 2 vols. Conard, 192829. (Vols. VII-VIII of Euvres complètes.) Accurate text.

Journal de Voyage. Ed. by Silvestre de Sacy. Club Français du Livre, 1954.

Lettres. Ed. by Arthur Armaingaud. Conard, 1939. (Vol. XI, pp. 159266 of Euvres complètes.) Accurate complete text.

\section{TRANSLATIONS}

The Essayes. Tr. by John Florio. London: V. Sims for E. Blount, 1603. First English version, often reprinted.

The Essays. Tr. by Charles Cotton. 3 vols. London: T. Basset, M. Gilliflower, and W. Hensman, 1685-86. Often reprinted and revised in the eighteenth and nineteenth centuries.

The Works. Essays tr. by Charles Cotton, revised by the younger William Hazlitt; Diary of a Journey and Letters tr. by the younger William Hazlitt. London: Templeman, 1842. Contains ten letters. Reprinted several times.

The Works. Essays tr. by Charles Cotton, revised by William Carew Hazlitt; Letters revised by William Carew Hazlitt. 10 vols. New York: Edwin C. Hill, 1910. Thirty-five letters, one of them dubious.

The Essays. Tr. by George B. Ives; introductions by Grace Norton. 4 vols. Cambridge, Mass.: Harvard University Press, 1925. Gives strata indications. Leaves all coarse passages untranslated.

The Essays. Tr. by E. J. Trechmann. 2 vols. London: Oxford University Press, 1927.

The Essays. Tr. by Jacob Zeitlin. 3 vols. New York: Knopf, 1931-36. Excellent Introduction and Notes. Gives strata indications.

The Journal of Montaigne's Travels. Tr. by W. G. Waters. 3 vols. London: John Murray, 1903.

The Diary of Montaigne's Journey to Italy in 1580 and 1581. Tr. by E. J. Trechmann. London: Hogarth Press, 1929.

Travel Journal, Letters. Tr. by Donald M. Frame. Stanford, Calif.: Stanford University Press, 1957. Pp. 859-1039, 1041-94, of The Complete Works of Montaigne.

\section{STUDIES AVAILABLE IN ENGLISH}

Auerbach, Erich. "L'Humaine Condition," in Mimesis: The Representation of Reality in Western Literature, tr. by Willard R. Trask. Princeton University Press, 1953. Pp. 285-311.

Buffum, Imbrie. Studies in the Baroque from Montaigne to Rotrou. New Haven: Yale University Press, 1957. 
Eliot, T. S. “The 'Pensées' of Pascal," in Selected Essays. New York: Harcourt, Brace, 1950 ed. Pp. 355-68. Also in Pascal, Pensées, Everyman ed. (Introduction).

Emerson, Ralph Waldo. "Montaigne; or, the Skeptic," in Representative Men.

Frame, Donald M. Montaigne's Discovery of Man: The Humanization of a Humanist. New York: Columbia University Press, 1955.

Gide, André. "Presenting Montaigne," tr. by Dorothy Bussy, in The Living Thoughts of Montaigne. New York and Toronto: Longmans, Green, 1939. Pp. 1-27.

Greene, Thomas M. "Montaigne and the Savage Infirmity," Yale Review (Winter, 1957), pp. 191-205.

Lüthy, Herbert. "Montaigne, or the Art of Being Truthful," Encounter (November, 1953), pp. 33-44.

Murry, John Middleton. "Montaigne: The Birth of the Individual," in Heroes of Thought. New York: Messner [1938]. Pp. 49-62.

Poulet, Georges. "Montaigne," in Studies in Human Time, tr. by Elliott Coleman. Baltimore: Johns Hopkins Press, 1956.

Spencer, Theodore. "Montaigne in America," Atlantic Monthly (March, 1946), pp. 91-97.

Woolf, Virginia. "Montaigne," in The Common Reader. New York: Harcourt, Brace, 1948. Pp. 87-100.

\section{STUDIES IN FRENCH AND GERMAN}

Bonnefon, Paul. Montaigne et ses amis. 2 vols. Colin, 1898.

Courteault, Paul. "Montaigne, maire de Bordeaux," in IVe Centenaire de la naissance de Montaigne, 1533-1933. Bordeaux: Delmas, 1933. Pp. 71-162.

Dreano, Mathurin. La Pensée religieuse de Montaigne. Beauchesne, 1936.

Friedrich, Hugo. Montaigne. Bern: Francke, 1949. In German.

Lanson, Gustave. Les Essais de Montaigne; étude et analyse. Mellottée [1930].

Moreau, Pierre. Montaigne, lhomme et l'œuvre. Boivin [1939].

Plattard, Jean. Montaigne et son temps. Boivin, 1933.

Strowski, Fortunat. Montaigne. Alcan, 1906. 2nd revised ed., Alcan, 1931.

-_-. Montaigne, sa vie publique et privée. Nouvelle Revue Critique, 1938.

Villey, Pierre. Les Essais de Michel de Montaigne. Sfelt, 1932.

- Les Sources et l'évolution des Essais de Montaigne. 2 vols. Hachette, 1908. 2nd revised ed., Hachette, 1933, 2 vols.

\section{BIBLIOGRAPHIES}

Strawn, Richard R., and Samuel F. Will. "Michel Eyquem de Montaigne," in Vol. II of D. C. Cabeen, A Critical Bibliography of French Literature (Syracuse, N.Y.: Syracuse University Press, 1956), pp. 155-87, 314. Most useful: hospitable but also critical.

Tannenbaum, Samuel A. Michel de Montaigne: A Concise Bibliography. New York: Samuel A. Tannenbaum, 1942. Nearly complete; not critical. 